\title{
PROBLEM BASED LEARNING PADA MATA PELAJARAN DASAR KOMPETENSI KEJURUAN TEKNIK MESIN
}

\author{
Yusep Sukrawan \\ Mumu Komaro \\ Dosen Jurusan Pendidikan Teknik Mesin, FPTK UPI
}

\begin{abstract}
ABSTRAK: Pada mata pelajaran Dasar Kompetensi Kejuruan Teknik Mesin (DKKTM) siswa SMK selalu menghadapi masalah yang berkaitan dengan ilmu keteknikan yang harus diselesaikan untuk membentuk kompetensi yang diharapkan Kurikulum SMK. Salah satu solusi yang dianggap cocok untuk mengatasi masalah tersebut adalah penerapan problem based learning, dengan metode pemecahan masalah berbasis diskusi kelompok. Dengan diterapkannya model tersebut diharapkan dapat meningkatkan hasil belajar dan aktivitas siswa. Metode penelitian yang digunakan adalah metode Penelitian Tindakan Kelas. Hasil penelitian menunjukkan bahwa penerapan problem based learning berbasis diskusi kelompok dapat meningkatkan hasil belajar siswa pada ranah kognitif dengan $N$-Gain 0,71 dalam kategori tinggi. Nilai rata-rata ranah afektif 82,12 pada kategori positif dan nilai rata-rata ranah psikomotor 90,9 pada kategori amat baik, sedangkan nilai ratarata aktivitas siswa pada kategori rendah.
\end{abstract}

Kata Kunci : problem based learning, teknik mesin

ABSTRACT: Basic Competency in Vocational subjects in Mechanical Engineering, vocational students have always faced the problems associated with engineering science to be done to establish the expected curriculum vocational competence. One solution that is considered suitable to solve the problem is the application of problem based learning, problem-solving method based discussion group. With the implementation of the model is expected to improve learning outcomes and student activities. The research method is a method of Classroom Action Research. The results showed that the application of problem based learning-based discussion group can improve student learning outcomes in the cognitive domain of the N-Gain 0.71 in the high category. The average value of 82.12 in the affective domain of the positive category and the average value of 90.9 in the psychomotor domain of very good category, while the average value of student activities at the low category.

Keyword: problem based learning, machanical engineering.

\section{PENDAHULUAN}

Saat ini banyak lulusan Sekolah Menengah Kejuruan (SMK) di Indonesia memiliki karakteristik: "hanya memahami teori, memiliki keterampilan individual, motivasi belajar hanya untuk lulus ujian, proses belajar bersifat pasif, hanya 
menerima informasi dari guru, serta menggunakan teknologi terpisah dari proses belajar. Padahal, sumber daya manusia yang diperlukan dalam pasar kerja, antara lain kemampuan menyelesaikan masalah berdasarkan konsep ilmiah, memiliki keterampilan team work, mempelajari bagaimana belajar yang efektif, berorientasi pada peningkatan terus-menerus dengan tidak dibatasi pada target tertentu saja. Setiap target yang tercapai akan terus-menerus ditingkatkan, membutuhkan pengetahuan terintegrasi antar disiplin ilmu untuk memecahkan masalah yang kompleks” (Turyanto, 2007).

Dalam mata pelajaran Dasar Kompetensi Kejuruan Teknik Mesin (DKKTM) siswa SMK selalu menghadapi masalah yang berkaitan dengan ilmu keteknikan yang harus diselesaikan untuk membentuk kompetensi yang diharapkan Kurikulum SMK.Masalah dalam pembelajaran DKKTM merupakan suatu "keharusan" untuk mengembangkan skill pribadi dalam menghadapi dunia kerja yang semakin ketat persaingannya.Karena itu selayaknya jika siswa SMK perlu berlatih menyelesaikan masalah. Pendidikan tidak hanya mengajarkan fakta dan konsep tetapi juga harus membekali siswa untuk memecahkan masalah yang dihadapi dalam dunia kerja.Dengan kondisi dan situasi yang demikian ini,"...pembelajaran yang penekanannya pada kompetensi dunia kerja semestinya adalah berdasarkan masalah (problem based learning). Problem based learning dapat membantu siswa membangun kecakapan sepanjang hidupnya dalam memecahkan masalah, kerja sama tim, dan berkomunikasi” (Amir, 2009:13).

Dibalik tuntutan dan harapan kurikulum yang telah diuraikan di atas, terdapat fenomena penyimpangan penerimaan konsep siswa kelas XI TFL SMKN 2 Kota Bandung terhadap mata pelajaran Dasar Kompetensi Kejuruan Teknik Mesin.Selama ini pelajaran Dasar Kompetensi Kejuruan Teknik Mesin dianggap sebagai mata pelajaran yang dirasa sulit, kurang diminati. Sehingga memberikan dampak negatif terhadap pencapaian nilai rata-rata tugas dan ulangan harian siswa kelas XI TFL SMKN 2 Kota Bandung pada mata pelajaran tersebut yang jauh dari standar minimal kelulusan. Sesuai dengan kurikulum yang diterapkan di SMKN 2 Kota Bandung (Keputusan Menteri Pendidikan Nasional Nomor 153/2003) bahwa dalam 
pembelajaran mata diklat produktif dalam hal ini DKKTM bahwa siswa dikatakan telah berkompeten atau lulus jika mendapat nilai KKM $\geq 70$.

Salah satu solusi untuk menanggulangi rendahnya hasil belajar siswa pada pelajaran DKKTM, adalah penerapan model pembelajaran. Dalam hal ini, solusi yang akan di ujicobakan adalah problem based learning. Mengapa problem based learning? Mengingat bahwa karakteristik DKKTM merupakan cabang ilmu yang memberikan teori-teori mendasar mengenai ilmu keteknikan yang harus dikuasai siswa untuk menyelesaikan masalah yang berkaitan dengan ilmu keteknikan, baik itu pada teori maupun praktek. Problem based learning dianggap cocok karena mampu menstimulus kemampuan siswa secara sistematis dan terstruktur, hal ini yang diharapkan pada pembelajaran di SMK yaitu mencapai kesuksesan belajar yang berorientasi pada penguasan kompetensi secara maksimal, ini ditunjukkan dari standar kelulusan KKM. Problem based learning dirancang untuk melatih siswa untuk mengembangkan kemampuan secara optimal sehingga melahirkan sikap profesional dalam memecahkan masalah yang timbul. Dengan PBL guru bukan mengajarkan siswa untuk memecahkan sebuah masalah, tetapi melatih siswa memberdayakan kemampuannya melalui mekanisme pemecahan masalah, sehingga dalam pembelajaran PBL siswa yang dituntut untuk lebih aktif dalam kegiatan pembelajaran baik melalui diskusi, serta siswa mampu mengaplikasikan setiap ide pada kondisi-kondisi nyata. Sehingga dengan pembelajaran problem based learning diharapkan mampu meminimalisir kekurangan-kekurangan dalam fenomena pembelajaran di SMK. Fenomena yang terjadi, bahwa siswa tidak mampu menghubungkan antara apa yang mereka pelajari dengan bagaimana pemanfaatannya dalam dunia kerja. Pendidikan bidang keteknikan selain memberikan teori-teori yang cukup, juga perlu memberikan contoh-contoh pemecahan masalah nyata dengan memanfaatkan teori-teori yang ada. 


\section{KAJIAN PUSTAKA}

\section{Pengertian Problem Based Learning}

Model problem based learning sebagai suatu model atau pendekatan dalam proses pembelajaran yang memiliki tiga karakteristik fundamental, yaitu: berpusat kepada siswa, menggabungkan antara teori dan praktek, serta mengaplikasikan pengetahuan dan keterampilan dalam mengembangkan suatu penyelesaian yang cocok dalam memecahkan suatu masalah.

Pada konteks ini, model PBL merupakan suatu model pembelajaran yang mengedepankan pemberdayaan kemampuan siswa secara optimal, guna memecahkan setiap masalah dengan memanfaatkan setiap pengetahuan atau informasi yang dimiliki sehingga mampu menemukan pengetahuan baru. Secara spontanitas siswa akan mencocokkan pengetahuan yang baru dengan pengetahuan yang dimilikinya kemudian membangun kembali aturan pengetahuannya jika terdapat aturan yang tidak sesuai, sehingga dalam hal ini guru harus mampu menciptakan suasana belajar yang dapat membantu siswa berlatih memecahkan masalah.

\section{Prinsip Pembelajaran Problem Based Learning}

Graaff dan Kolmos (2009: 11) mengemukan bahwa prinsip pembelajaran dengan model problem based learning terdapat tiga prinsip, yaitu: belajar (learning), isi (content) dan sosial (social). Ketiga prinsip tersebut digambar dalam sebuah bagan sebagai berikut:

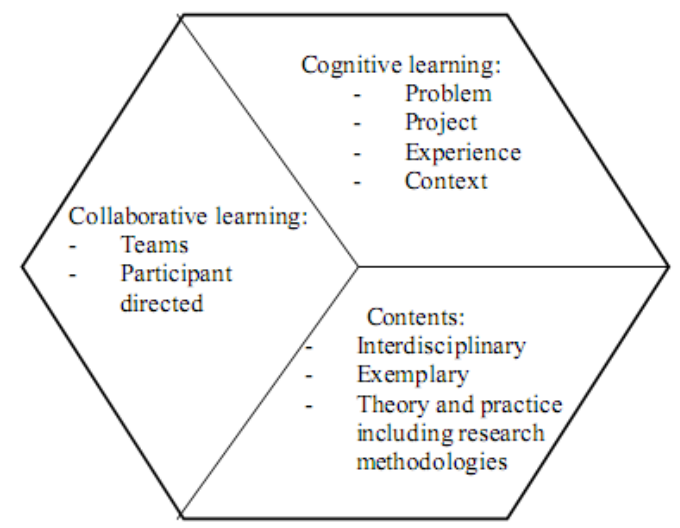

(Sumber: Graaff dan Kolmos, 2009:11)

Gambar 1. Probel Based Learning Principle 


\section{a. Cognitive learning}

Cognitive learning berarti bahwa belajar adalah diorganisir disekitar masalah dan akan dilakukan dalam proyek. Ini adalah prinsip utama untuk pengembangan motivasi. Sebuah masalah (a wonder, an anomaly, contradiction, needs, etc.).sebagai titik awal untuk proses belajar, tempat belajar dalam konteks, dan dasar belajar pada pengalaman siswa

\section{b. Contents}

Contents approach menyangkut tentang pembelajaran interdisipliner. Contents approach ini merupakan praktik langsung bahwa hasil belajar adalah tujuan umum keseluruhan kurikulum. Biasanya, pendekatan masalah mendukung hubungan antara teori dan praktek dengan fakta bahwa proses belajar melibatkan suatu pendekatan analitis dengan menggunakan teori dalam analisis masalah dan metode pemecahan masalah

\section{c. Collaborative learning}

Collaborative learning merupakan pendekatan pembelajaran sosial (social approach). Aspek belajar kelompok mendorong proses belajar sebagai tindakan sosial dimana belajar terjadi melalui dialog dan komunikasi. Selanjutnya, para siswa tidak hanya belajar dari satu sama lain, tetapi mereka juga belajar untuk berbagi pengetahuan dan mengatur sendiri melalui proses pembelajaran kolaboratif. Pendekatan sosial juga mencakup konsep belajar individual, yang ditunjukkan dari pola pikir mereka sendiri dari proses belajar dan, terutama pada perumusan masalah.

\section{Karakteristik Model Problem Based Learning}

Kunci utama dalam model problem based learning terletak pada masalah yang dihadapkan pada siswa. Masalah yang diberikan dapat bersumber dari guru, artikelartikel, surat kabar, buku teks bahkan teks-teks yang diunduh dari internet. Masalah digunakan untuk memotivasi siswa mengindentifikasi dan mencari konsep/prinsip untuk menganalisis masalah yang diberikan. 


\section{Langkah-Langkah Pembelajaran Model Problem Based Learning}

Langkah-langkah pembelajaran problem based learning terdiri dari lima tahapan utama yang dimulai dari guru memperkenalkan siswa dengan suatu situasi masalah dan diakhiri dengan penyajian dan analisis hasil kerja siswa. Untuk lebih jelasnya kelima tahapan pembelajaran problem based learning adalah seperti pada Tabel 1 berikut.

Tabel 1. Langkah-langkah Pembelajaran Problem Based Learning

\begin{tabular}{|c|l|}
\hline Tahap & \multicolumn{1}{c|}{ Tingkah Laku Guru } \\
\hline Tahap -1 & $\begin{array}{l}\text { Guru menjelaskan tujuan pembelajaran, menjelaskan logistik } \\
\text { yang dibutuhkan, mengajukan fenomena atau demonstrasi } \\
\text { atau cerita untuk memuculkan masalah, memotivasi siswa } \\
\text { untuk terlibat dalam pemecahan masalah yang dipilih. }\end{array}$ \\
\hline Tahap-2 & $\begin{array}{l}\text { Guru membantu siswa untuk mendefinisikan dan } \\
\text { mengorganisasikan tugas belajar yang berhubungan dengan } \\
\text { masalah tersebut. }\end{array}$ \\
\hline $\begin{array}{c}\text { Mengorganisai siswa untuk belajar } \\
\text { individual maupun kelompok }\end{array}$ & $\begin{array}{l}\text { Guru mendorong siswa untuk mengumpulkan informasi yang } \\
\text { sesuai, melaksanakan eksperimen, untuk mendapatkan } \\
\text { penjelasan dan pemecahan masalah. }\end{array}$ \\
\hline $\begin{array}{c}\text { Tahap-4 } \\
\text { Mengembangkan dan menyajikan } \\
\text { hasil karya }\end{array}$ & $\begin{array}{l}\text { kuru membantu siswa dalam merencanakan dan menyiapkan } \\
\text { membantu mereka untuk berbagi tugas dengan temannya. }\end{array}$ \\
\hline Tahap-5 & $\begin{array}{l}\text { Guru membantu siswa untuk melakukan refleksi atau } \\
\text { evaluasi terhadap penyelidikan mereka atau proses-proses } \\
\text { yang mereka gunakan. }\end{array}$ \\
\hline $\begin{array}{c}\text { Menganalisis dan mengevaluasi } \\
\text { proses pemecahan masalah }\end{array}$
\end{tabular}

(Sumber: Ibrahim \& Nur, 2000 dalam Trianto, 2007: 72)

\section{METODE}

Metode Penelitian yang digunakan adalah Penelitian Tindakan Kelas (PTK).PTK merupakan salah satu upaya guru atau praktisi dalam bentuk berbagai kegiatan yang dilakukan untuk memperbaiki, dan atau meningkatkan mutu pembelajaran di kelas. PTK merupakan kegiatan yang langsung berhubungan dengan tugas guru di lapangan. Singkatnya PTK merupakan penelitian praktis yang dilakukan di kelas dan bertujuan untuk memperbaiki praktik pembelajaran yang ada.

Model dalam PTK ada 4 model diantara: 1). Model Kemmis dan Taggart; 2). Model Ebbut; 3). Model Elliot; 4). Model McKernan. Model yang dipilih pada 
penelitian ini adalah model Kemmis \& Taggart. Hal ini dikarenakan pada tahap tindakan dan observasi dilakukan secara bersamaan, dan hal ini yang dipandang cocok dengan proses pembelajaran di sekolah. Pada pembelajaran disekolah tentunya setiap aktivitas/kegiatan yang dilakukan pada proses pembelajaran perlu dipantau. Hal ini juga dipertegas oleh Kemmis yang dikutip oleh Suharsimi, Suhardjono, Supardi (2009:102) bahwa theory and action might develop together from application of the scientific approach. Kemmis merupakan penggalak istilah "penelitian tindakan pendidikan”. Pada penelitian ini aspek yang diamati dalam setiap siklusnya adalah kegiatan atau aktifitas siswa saat mata pelajaran DKKTM dengan penerapan model pembelajaran problem based learning untuk melihat perubahan tingkah laku siswa, untuk mengetahui kemajuan belajarnya yang akan berpengaruh terhadap hasil belajar dengan alat pengumpul data seperti lembar tes, observasi, dan dokumentasi.
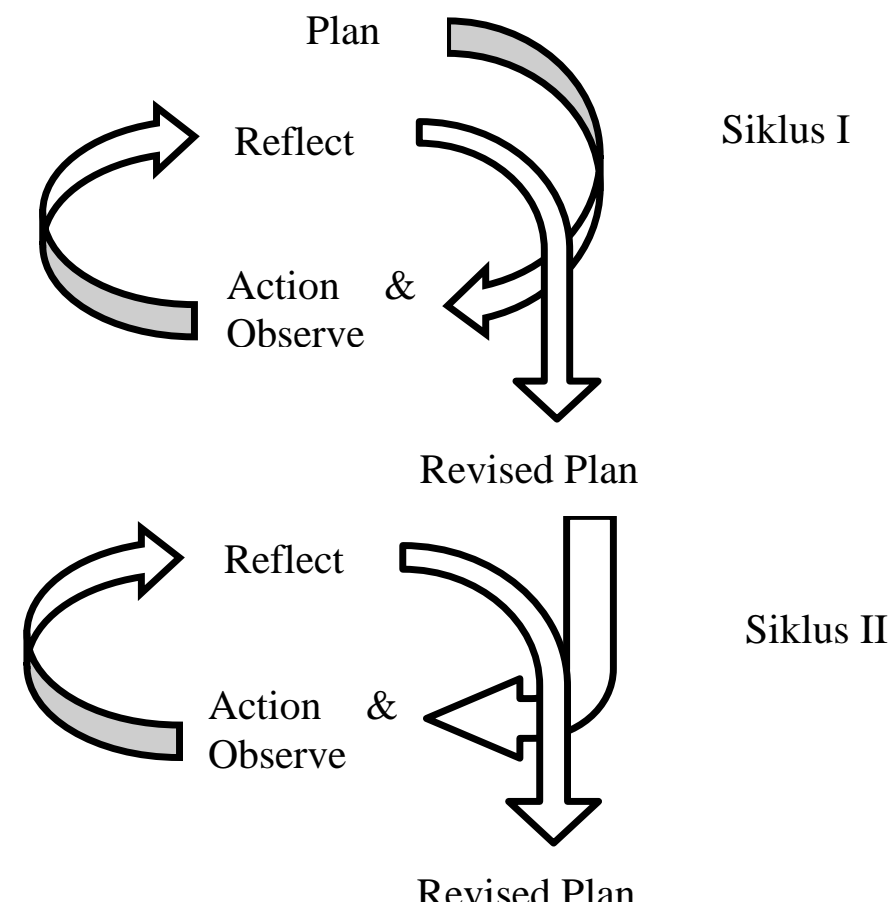

Gambar 2. Siklus Penelitian Tindakan Kelas Kemmis dan Taggart (Depdikbud, 1999:6) 
Gambar 2 di atas, tampak bahwa di dalamnya terdiri dari dua perangkat komponen yang dapat dikatakan sebagai dua siklus.Untuk pelaksanaan sesungguhnya, jumlah siklus sangat bergantung kepada permasalahan yang perlu diselesaikan. Apabila permasalahan terkait belum terselesaikan dalam dua siklus maka perlu dilakukan siklus selanjutnya yang disertai dengan tindak lanjut dari penyelesaian masalah dari siklus sebelumnya.

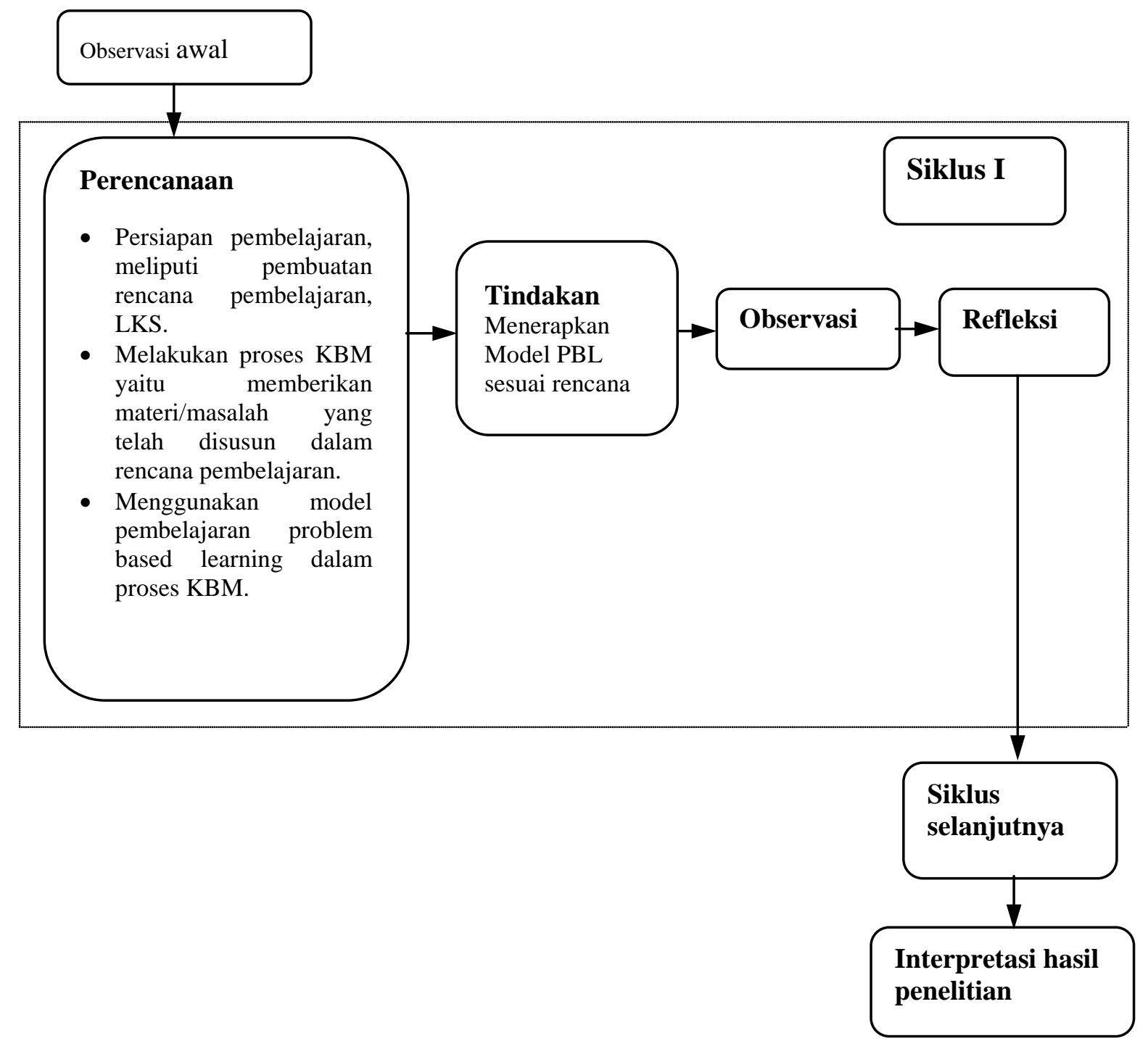

Gambar 3. Alur Kerja PTK yang Akan Dilaksanakan 


\section{Prosedur Penelitian}

Prosedur penelitian terdiri dari 4 tahap, yakni perencanaan, melakukan tindakan, observasi dan refleksi. Refleksi dalam tahap siklus dan akan berulang kembali pada siklus-siklus berikutnya. Aspek yang diamati dalam setiap siklusnya adalah kegiatan atau aktifitas siswa saat mata pelajaran DKKTM dengan penerapan model pembelajaran problem based learning untuk melihat perubahan tingkah laku siswa, untuk mengetahui tingkat kemajuan belajarnya yang akan berpengaruh terhadap hasil belajar.

Rancangan penelitian, penelitian tindakan kelas disusun menggunakan prosedur sebagai berikut:

1. Observasi awal dan identifikasi masalah

2. Perencanaan (Planning)

3. Tahap Pelaksanaan Tindakan (action)

\section{a. Siklus ke -1}

Pembelajaran pada siklus ke-1 berisi penyampaian materi tentang fungsi sambungan las dan jenis-jenis sambungan las. Kemudian dilanjutkan dengan pengajuan masalah autentik dalam LKS untuk diselesaikan secara individu dan kelompok, dilakukan pembahasan, menganalisis, dan menarik kesimpulan secara bersama-sama. Dalam tahap ini peneliti menjelaskan pembelajaran sesuai rencana yang dituangkan dalam rencana pembelajaran, namun tindakan yang dilakukan tidak mutlak dikendalikan oleh perencana.

\section{b. Siklus ke- 2}

Pelaksanaan proses pembelajaran pada siklus kedua ini berdasarkan hasil refleksi pada siklus pertama dan rencana perbaikan pembelajaran yang telah disusun untuk siklus kedua. Tahapan proses pembelajaran pada siklus kedua sama seperti pembelajaran siklus pertama. Pada akhir siklus akan diberikan soal tes (pos ts) dalam bentuk soal essay untuk mengetahui hasil belajar (kemampuan penguasaan materi). 


\section{c. Siklus ke- 3}

Pelaksanaan proses pembelajaran pada siklus ketiga ini berdasarkan hasil refleksi pada siklus kedua dan rencana perbaikan pembelajaran yang telah disusun untuk siklus ketiga. Tahapan proses pembelajaran pada siklus ketiga sama seperti pembelajaran siklus kedua. Padaakhir siklus akan diberikan soal tes(pos tes) dalam bentuk soal essay untuk mengetahui hasil belajar (kemampuan penguasaan materi).

\section{Teknis Analisis Data dan Interpretasi Data}

\section{Teknik Analisis Data}

Analisis data dalam penelitian ini, menggunakan analisis deskriptif.

a. Analisis hasil pengamatan kegiatan pembelajaran

Analisis hasil pengamatan selama kegiatan pembelajaran berlangsung dilakukan observasi mengenai aktivitas guru dan siswa.

1) Aktivitas siswa

Rata-rata aktivitas siswa di dalam kelompok

$$
\mathrm{A}=\frac{\mathrm{B}}{\mathrm{C}} \times 100 \%
$$

Keterangan:

$\mathrm{A}=$ presentase aktivitas siswa (\%)

$\mathrm{B}=$ jumlah siswa yang aktif teramati dibagi jumlah frekuensi aktivitas yang dilakukan siswa di dalam kelompok.

$\mathrm{C}=$ jumlah siswa di dalam kelompok.

Selanjutnya data perolehan hasil akan dibagi ke dalam lima kategori skala

Tabel 2. Klasifikasi Aktivitas Siswa

\begin{tabular}{|c|c|}
\hline Presentase & Kategori \\
\hline $80 \% \leq \mathrm{A} \leq 100 \%$ & Sangat tinggi \\
\hline $60 \% \leq \mathrm{A}<80 \%$ & Tinggi \\
\hline $40 \% \leq \mathrm{A}<60 \%$ & Sedang \\
\hline $20 \% \leq \mathrm{A}<40 \%$ & Rendah \\
\hline $0 \% \leq \mathrm{A}<20 \%$ & Sangat rendah \\
\hline
\end{tabular}

Sumber: Laksmini (Hermansyah, 2007: 31) 


\section{b. Analisis tes hasil belajar}

Data hasil tes belajar berisi soal uraian/essay untuk menghindari pengundian pilihan jika berupa soal pilihan ganda, dan juga untuk melatih tingkat pemecahan masalah siswa. Analisis data dengan cara membandingkan transkip setiap instrumen kegiatan atau hasil kerja siswa. Teknik analisis data yang digunakan adalah analisis data kualitatif dengan menggunakan deskripsi proses pembelajaran dan analisis data kuantitatif dengan mencari rata-rata hasil belajar siswa tiap siklus. Teknik analisis data untuk mengetahui efektivitas peningkatan hasil belajar dalam penelitian ini menggunakan teknik Normalized Gain.

c. Penskoran hasil tes

Setiap bentuk tes berbeda teknik penskorannya apalagi kalau jumlah tes itu bervariasi. Untuk tes objektif seperti benar salah, menjodohkan, memilih, dan lainlainnya, penskorannya berbeda dengan cara penskoran tes subjektif. Selain itu jumlah dan rentang tes perlu dipertimbangkan guna mendapatkan penskoran yang konsisten.Pada umumnya rentang skor yang sering digunakan untuk tes subjektif adalah $0 \mathrm{~s} / \mathrm{d}$ 1.Karena dalam penelitian ini menggunakan tes essay/uraian dengan jumlah tes beberapa butir tes maka penskorannya dilakukan dengan pembobotan.Nilai akhir dari hasil tes diambil dari nilai keseluruhan butir soal, sedangkan nilai butir soal diperoleh dengan menjumlahkan skor yang diperoleh setiap butir soal dibagi skor maksimum dikali bobot soal.

\section{Interpretasi Data}

Pada tahap ini, peneliti melakukan interpretasi atau menggambarkan temuantemuan penelitian berdasarkan landasan teoritis yang telah dipilih. Hasil interpretasi ini diharap dapat memperoleh makna yang cukup berarti sebagai bahan untuk kegiatan tindakan selanjutnya atau untuk kepentingan peningkatan kinerja guru.

\section{a. Keterlaksanaan Model}

Keterlaksanaan model dapat diinterpretasikan dari hasil observasi terhadap guru yang di isi oleh guru mata pelajaran DKKTM atau observer, adapun interpretasinya disepakati secara bersama-sama antara peneliti dan observer, sehingga 
tidak terjadi kesalahfahaman pada waktu pelaksanaan penelitian, adapun interpretasinya adalah sebagai berikut:

Tabel 3. Interpretasi Skor Keterlaksanaan Model Pembelajaran

\begin{tabular}{|c|c|}
\hline Skor & Interpretasi \\
\hline 1 & Kurang \\
\hline 2 & Sedang \\
\hline 3 & Baik \\
\hline 4 & Baik sekali \\
\hline
\end{tabular}

b. Hasil Belajar pada Aspek Afektif

Peningkatan kemampuan siswa pada aspek afektif dapat terlihat apabila datadata yang dihasilkan dari lembar observasi siswa pada aspek afektif sudah diperoleh, lembar observasi tersebut dapat dilihat pada lampiran. Sedangkan untuk hasil observasinya terdapat pada lampiran. lembar obsevasi ini kemudian di interpretasikan dalam bentuk $\mathrm{IP}_{\mathrm{K}}$ aspek afektif, sebagai berikut:

Tabel 4. Kategori Tafsiran Indeks Prestasi Kelompok untuk Aspek Afektif

\begin{tabular}{|l|c|l|}
\hline No & Kategori Prestasi Kelas & Interpretasi \\
\hline 1 & $0 \leq \mathrm{IP}_{\mathrm{k}}<30$ & Sangat Negatif \\
\hline 2 & $30 \leq \mathrm{IP}_{\mathrm{k}}<50$ & Negatif \\
\hline 3 & $50 \leq \mathrm{IP}_{\mathrm{k}}<70$ & Netral \\
\hline 4 & $70 \leq \mathrm{IP}_{\mathrm{k}}<90$ & Positif \\
\hline 5 & $90 \leq \mathrm{IP}_{\mathrm{k}} \leq 100$ & Sangat Positif \\
\hline
\end{tabular}

Sumber: (Panggabean , 2006: 43)

c. Hasil Belajar pada Aspek Psikomotor

Peningkatan kemampuan siswa pada aspek psikomotor tiap siklusnya diperoleh dari lembar observasi siswa pada aspek psikomotor, lembar observasi tersebut dapat dilihat pada lampiran. Hasil dari aspek psikomotor kemudian diinterpretasikan dalam bentuk $\mathrm{IP}_{\mathrm{K}}$ aspek psikomotor, sebagai berikut:

Tabel 5. Kategori Tafsiran Indeks Prestasi Kelompok untuk Aspek Psikomotor

\begin{tabular}{|l|c|l|}
\hline No & \multicolumn{1}{|l|}{$\mathbf{I P}_{\mathbf{K}}$} & Kategori \\
\hline 1 & $90 \leq \mathrm{IP}_{\mathrm{k}} \leq 100$ & Amat baik \\
\hline 2 & $80 \leq \mathrm{IP}_{\mathrm{k}}<90$ & Baik \\
\hline 3 & $70 \leq \mathrm{IP}_{\mathrm{k}}<80$ & Cukup \\
\hline 4 & $50 \leq \mathrm{IP}_{\mathrm{k}}<70$ & Tidak terampil \\
\hline 5 & $0 \leq \mathrm{IP}_{\mathrm{k}}<50$ & Sangat Tidak Terampil \\
\hline
\end{tabular}

(Sumber: Depdiknas, 2008:32) 


\section{Gain Ternormalisasi (N-Gain)}

Teknik untuk mengetahui efektivitas peningkatan hasil belajar dalam penelitian ini menggunakan teknik normalized gain. Menyatakan gain (peningkatan) dalam hasil proses pembelajaran tidaklah mudah, dengan menggunakan gain absolut (selisih antara skor pre test dan post test) kurang dapat menjelaskan mana sebenarnya yang dikatakan gain tinggi dan mana yang dikatakan gain rendah. Misalnya, siswa yang memiliki gain 2 dari 4 ke 6 dan siswa yang memiliki gain dari 6 ke 8 dari suatu soal dengan nilai maksimal 8. Gain absolut menyatakan bahwa kedua siswa memiliki gain yang sama. Oleh karena itu dengan mengetahui rata-rata nilai G (normalized gain) dari masing-masing kelompok sehingga kita akan dapat mengetahui keefektifan peningkatan hasil belajar dari masing-masing kelompok tersebut. Menyikapi kondisi bahwa siswa yang memiliki gain absolut sama belum tentu memiliki gain hasil belajar yang sama. Hake (1998) mengembangkan sebuah alternatif untuk menjelaskan gain yang disebut gain ternormalisasi (normalized gain). Gain ternormalisasi (N-gain) diformulasikan dalam bentuk persamaan seperti dibawah ini:

$$
\mathrm{N}-\text { Gain }=\frac{\text { Skor Post test }- \text { Skor Pre test }}{\text { Skor Ideal-Skor Pre test }}
$$

Kategori gain ternormalisasi disajikan pada tabel di bawah ini.

Tabel 6 Kriteria Normalized Gain

\begin{tabular}{|l|l|}
\hline Skor N-Gain & $\begin{array}{l}\text { Kriteria Normalized } \\
\text { Gain }\end{array}$ \\
\hline $0,70<$ N-Gain & Tinggi \\
\hline $0,30 \leq$ N-Gain $\leq 0,70$ & Sedang \\
\hline N-Gain $<0,30$ & Rendah \\
\hline
\end{tabular}

(Hake, 1998)

\section{HASIL PENELITIAN DAN PEMBAHASAN}

\section{Aktivitas Guru}

Gambaran peningkatan aktivitas guru setiap siklus pada pembelajaran ditunjukkan pada Diagram di bawah ini: 


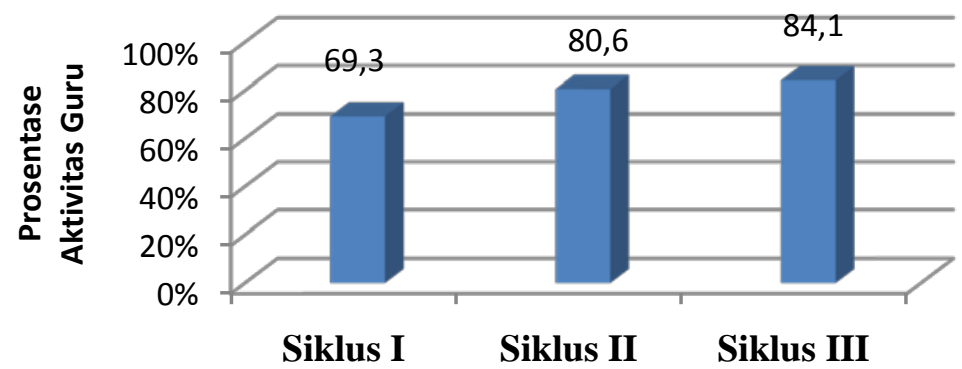

Gambar 4. Diagram Perkembangan Aktivitas Guru

Berdasarkan Diagram di atas diperoleh gambaran aktivitas guru pada siklus I sebesar 69,3\% meningkat pada siklus II menjadi 80,6\% dan pada siklus III kembali meningkat menjadi 84,1\%. Peningkatan ini dikarenakan pada setiap kali selesai PBM, peneliti melakukan diskusi dengan observer dan guru mata pelajaran untuk meminta saran demi perbaikan pada siklus-siklus selanjutnya. Hasil observasi menunjukkan keseluruhan aspek guru dalam pembelajaran dengan model problem based learning ini sudah berjalan dengan baik. Aktivitas guru selama proses pembelajaran seperti menyampaikan tujuan pembelajaran, memotivasi siswa, mengorganisasikan siswa, membimbing kelompok, mengembangkan penyajian hasil karya, dan mengevaluasi sudah sesuai dengan pembelajaran problem based learning. Dalam proses pembelajaran, guru sebagai motivator dan fasilitator telah mampu menciptakan suatu kondisi dimana siswa lebih aktif dalam membangun pengetahuan melalui berbagai aktivitas belajarnya.

\section{Aktivitas Siswa}

Berdasarkan Diagram 5 terlihat bahwa pada setiap siklusnya nilai rata-rata aktivitas menunjukkan peningkatan yang tidak signifikan yaitu 21,3 \% pada siklus I; 24,8 \% pada siklus II; 27,06\% pada siklus III. Aktivitas siswa tiap siklusnya menunjukkan peningkatan jumlah siswa yang melakukan aktivitas pembelajaran tersebut, walaupun dalam kategori sedang. Setiap jenis aktivitas yang dilakukan siswa sudah mengarah kepada pendekatan problem based learning dalam jumlah 
peningkatan yang rendah. Jenis aktivitas visual and listening activities, oral and mental activities, writing activitites setiap siklus mengalami peningkatan dalam kategori rendah, dalam hal ini sudah dirasa cukup karena setiap siklusnya menunjukkan jumlah peningkatan siswa yang melakukan aktivitas tersebut. Diharapkan dengan penyajian masalah otentik siswa menjadi tertarik untuk dapat memecahkan masalah tersebut, hal ini dianggap penting karena apabila siswa tersebut suatu saat mendapat masalah yang sama seperti yang diberikan pada pembelajaran ini (contohnya pada saat praktek), siswa akan mempunyai pengalaman untuk menyelesaikan masalah tersebut. Disinilah letak salah satu keunggulan model problem based learning yang dapat mengsinkronkan pengetahuan antara teori dan praktek dengan berbekal experiental learning untuk menyelesaikannya. Namun pada hasil penelitian ini nilai rata-rata aktivitas siswa tidak menunjukkan peningkatan jumlah nilainya tetapi menunjukkan jumlah siswa yang melakukan aktivitas tersebut setiap 10 menit dari hasil pemantauan.

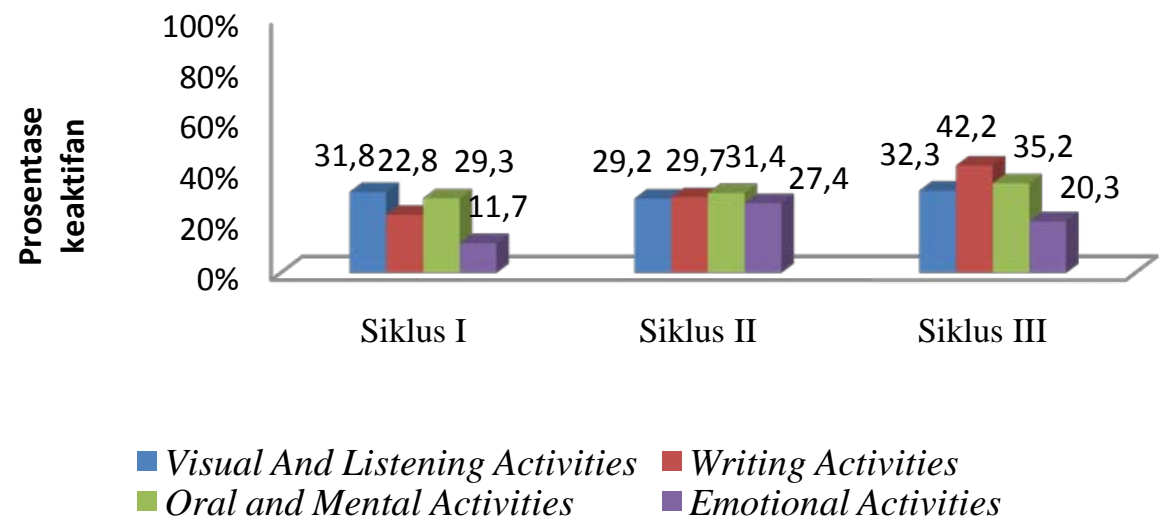

Gambar 5. Diagram Perkembangan Aktivitas Siswa

Data di atas menyimpulkan bahwa model problem based learning meningkatkan aktivitas siswa pada kategori rendah pada proses pembelajaran. Diharapkan dengan model problem based learning aktivitas siswa seharusnya menunjukkan pada kategori sangat tinggi, dengan kategori tersebut siswa akan merasakan aktivitas yang sangat bermanfaat yang dapat diterapkan untuk 
menyelesaikan masalah pada contoh kasus praktek. Hal ini sesuai dengan pendapat Amir (2009:13) bahwa: "Problem based learning dapat membantu siswa membangun kecakapan sepanjang hidupnya dalam memecahkan masalah, kerja sama tim, dan berkomunikasi”.

Peningkatan aktivitas pembelajaran setiap siklusnya dengan pembelajaran problem based learning menggunakan metode diskusi kelompok ini relevan dengan apa yang diutarakan oleh Ahmad (2009:6) bahwa problem based learning yang dilaksanakan melalui diskusi kelompok dapat menghasilkan:
a. keterampilan penelusuran kepustakaan
b. keterampilan membaca
c. keterampilan/kebiasaan membuat catatan
d. kemampuan kerjasama dalam kelompok
e. keterampilan berkomunikasi
f. keterbukaan
g. berpikir analitik
h. kemandirian dan keaktifan belajar
i. wawasan dan keterpaduan ilmu pengetahuan

\section{Hasil Belajar Ranah Kognitif}

Gambaran peningkatan hasil siswa pada setiap siklus ditunjukkan pada Diagram di bawah ini :

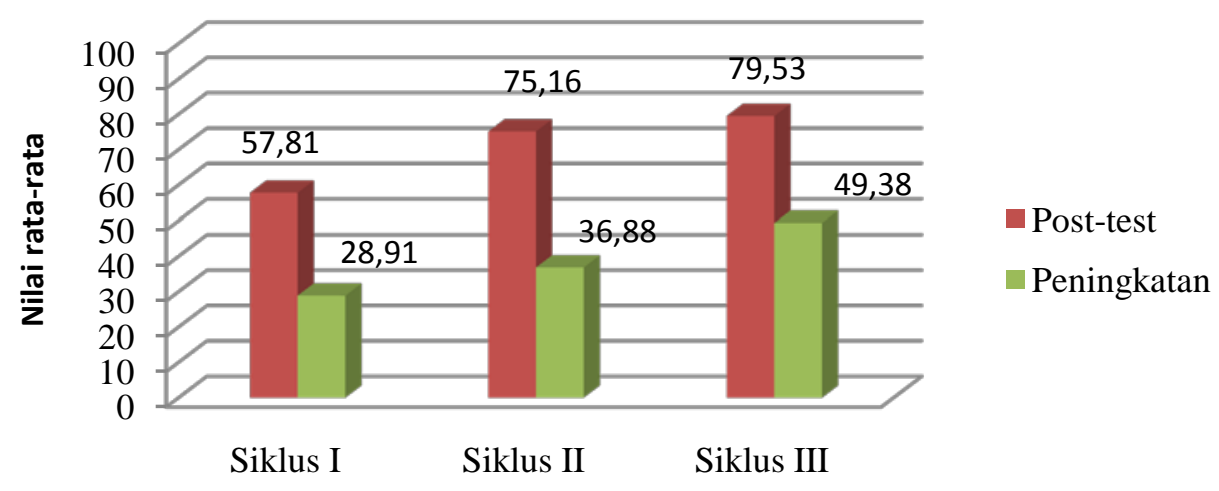

Gambar 6. Diagram Perkembangan Hasil Belajar Tiap Siklus 
Peningkatan hasil belajar siswa setiap siklus menunjukkan efektivitas belajar dengan model problem based learning. Nilai efektivitas itu diperoleh dari N-Gainnya yaitu pada kategori tinggi. Sementara untuk peningkatan hasil belajar siswa yang dinyatakan dalam gain ternormalisasi untuk setiap siklus pembelajaran dengan model problem based learning diperlihatkan pada Diagram di bawah ini :

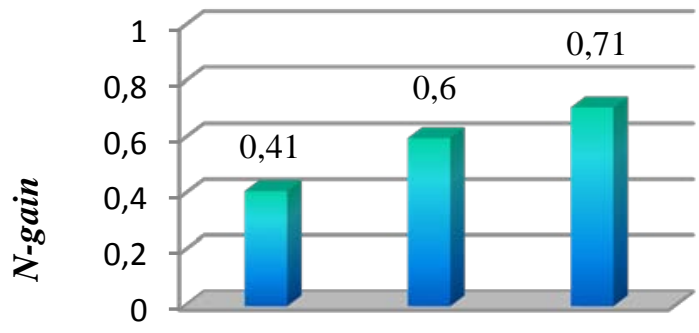

Siklus I Siklus II Siklus III

Gambar 7. Diagram Perkembangan Hasil Belajar dalam Gain

Diagram diatas dapat diketahui bahwa urutan perkembangan indeks prestasi kelompok (IPK) untuk ranah kognitif dari siklus pertama sampai siklus ke tiga cenderung meningkat yaitu dari kategori sedang ke kategori tinggi.Pada siklus III di dapat hasil belajar ranah kognitif mencapai ketuntasan belajar 100\%. Hal ini terlihat bahwa semua siswa lulus mencapai Kriteria Kelulusan Minimum $\geq 70$.

Hasil pembelajaran ranah kognitif mengalami kenaikan pada saat setelah diberi perlakuan model problem based learning. Dengan demikian, hasil belajar yang dihasilkan dengan perlakuan model problem based learning dapat mencapai ketuntasan belajar pada Kriteria Kelulusan Minimum (KKM) 70 pada K ompetensi Dasar Mendeskripsikan Proses Dasar Pengelasan dengan level pencapaian aplikasi pada ranah kognitif. Pencapaian hasil belajar pada ranah kognitif ini dipengaruhi oleh struktur model pembelajaran problem based learning yang menggunakan masalah sebagai awal untuk menggali informasi yang diperlukan. Dimana dengan model problem based learning masalah yang dirancang disesuaikan dengan kebutuhan siswa SMK, yaitu untuk siap bekerja baik itu pada saat praktek. 


\section{Hasil Belajar Ranah Psikomotor}

Hasil observasi terhadap ranah psikomotor selama proses pembelajaran untukmasing-masing siklus ditunjukan pada diagram berikut:

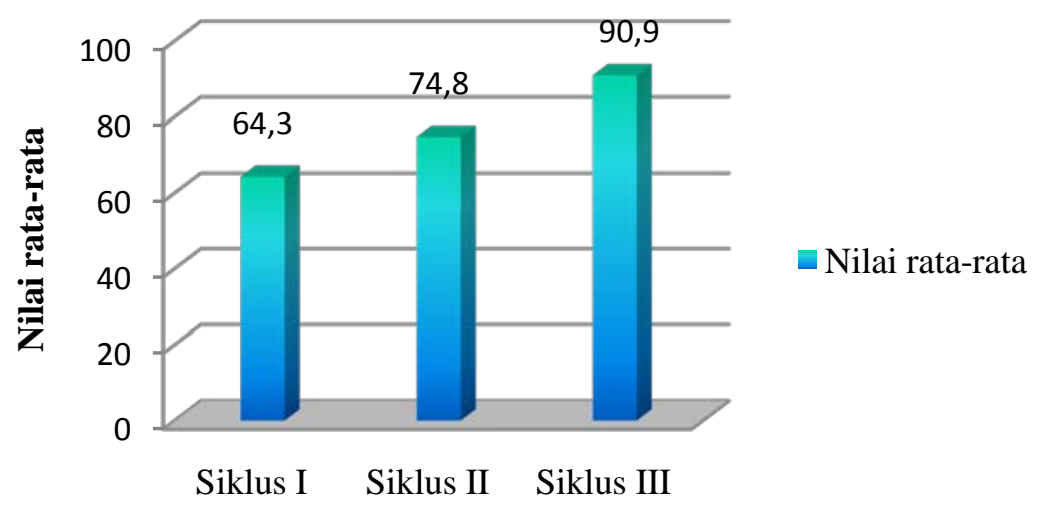

Gambar 8. Diagram Perkembangan Hasil Belajar Ranah Psikomotor

Diagram di atas menunjukkan hasil ranah psikomotor pada siklus ke-I sampai siklus ke-III cenderung mengalami peningkatan yakni dari kategori tidak terampil ke kategori sangat terampil/baik. Pengelompokan siswa secara heterogen dalam kemampuan akademik maupun gender, hal ini dapat dilihat bahwa semua siswa tidak malu lagi untuk berdiskusi, saling mengajarkan dan saling mendukung serta kelompok heterogen ini memudahkan atau membantu guru dalam mengelola kelas karena siswa yang berkemampuan tinggi tersebar pada tiap kelompok yang akhirnya dapat membantu siswa yang berkemampuan rendah.Hal ini juga dipicu dengan pembagian kelompok yang tanpa keharusan harus masuk kelompok tertentu. Maksudnya dalam membentuk kelompok diskusi siswa diberi kebebasan untuk memilih teman satu kelompok diskusinya, hal ini agar siswa lebih fleksibel dengan teman diskusinya dalam proses pembelajaran. Dengan model problem based learning, pencapaian hasil belajar ranah psikomotor dapat memenuhi KKM. Harapannya dengan metode diskusi kelompok diharapkan dapat membangun sikap team work yang berguna pada saat praktek, dimana ini sesuai dengan tujuan problem based learning yaitu integrasi antara teori dan praktek. 


\section{Hasil Belajar Ranah Afektif}

Hasil observasi terhadap ranah afektif selama proses pembelajaran untuk masing-masing siklus ditunjukan pada diagram berikut ini:

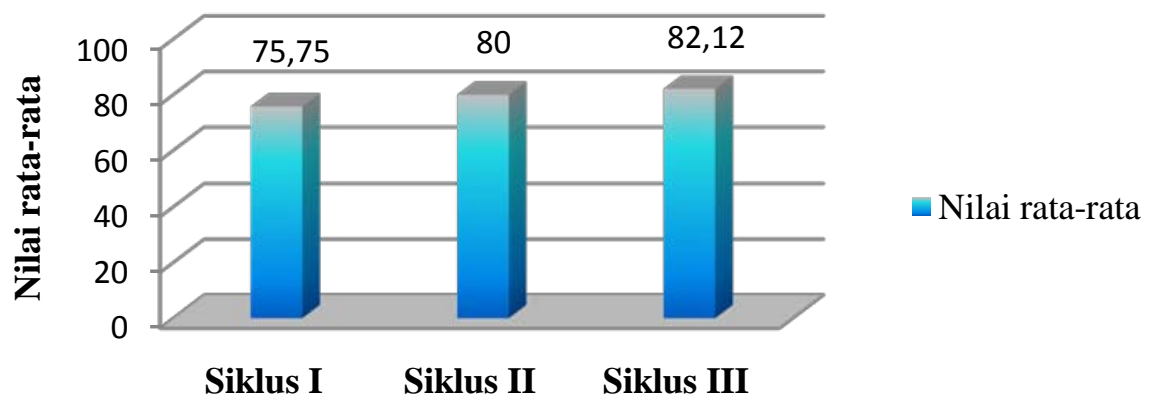

Gambar 9. Diagram Perkembangan Hasil Belajar Ranah Afektif

Hasil penelitian terhadap aspek afektif untuk masing-masing siklus diatas dapat dinyatakan bahwa pembelajaran sebagai berikut: 1) Disiplin meningkat dari kategori netral ke kategori sangat positif ; 2) Perhatian meningkat dari kategori netral ke kategori sangat positif. Dari kesemua hasil belajar aspek afektif dapat disimpulkan bahwa hasil belajar aspek afektif cenderung mengalami peningkatan. Peningkatan hasil belajar aspek afektif ini disebabkan karena keterlaksanaan model pembelajaran problem based learning yang dikembangkan dapat berjalan dengan baik.

Pencapaian hasil belajar dari setiap ranah yaitu, ranah kognitif, afektif dan psikomotor setiap siklusnya mengalami kenaikan pada saat setelah diberi perlakuan model problem based learning. Dengan demikian, hasil belajar yang dihasilkan dengan perlakuan model problem based learning dapat mencapai ketuntasan belajar pada mata pelajaran Dasar Kompetensi Kejuruan Teknik Mesin pada Kompetensi Dasar Mendeskripsikan Proses Dasar Pengelasan. Hal ini sejalan dengan pendapat Smith dalam Amir (2009:27) bahwa dengan problem based learning siswa akan:

Meningkatkan kecakapan pemecahan masalahnya, lebih mudah mengingat, meningkat pemahamannya, meningkat pengetahuannya yang relevan dengan dunia praktik/kerja, mendorong mereka penuh pemikiran, membangun kemampuan kepemimpinan dan kerja sama, kecakapan belajar, dan memotivasi siswa. 
Model problem based learning telah berhasil memperbaiki hasil belajar siswa, proses pemecahan masalah, sikap dan kebiasan belajar siswa. Peningkatan hasil belajar siswa ini menunjukkan bahwa penerapan model problem based learning dapat membuat materi pelajaran yang menurut siswa termasuk sukar menjadi mudah untuk dipahami oleh siswa. Peningkatan ini tidak terlepas dari peranan model pembelajaran yang diterapkan, dimana keunggulan model pembelajaran problem based learning sehingga dapat meningkatkan hasil belajar siswa sesuai yang diungkapkan oleh Saptono (2003:4) yaitu:

a. Menggunakan metode belajar yang menekankan pada pemahaman bukan menghafal.

b. Memotivasi pada konteks professional yang relevan dengan praktek masa depan.

c. Integrasi antara teori dan praktek.

d. Penekanan pada kemampuan selain pengetahuan dan keterampilan (misalnya belajar seumur hidup/life long learner, bekerja dalam kelompok kecil).

e. Lebih lama diingat/tidak mudah lupa dan diterapkan dengan masalah yang terdapat didunia kerja.

f. Siswa dapat melihat relevansi dari apa yang mereka pelajari untuk tugas-tugas masa depan mereka.

g. Siswa lebih banyak melakukan kegiatan daripada guru. Mereka menjadi lebih bersemangat, termotivasi, bukti perilaku yang lebih matang, dan mendapatkan suatu dasar pengetahuan dasar mengesankan.

\section{KESIMPULAN}

Berdasarkan analisis data dari temuan penelitian yang diperoleh dilapangan selama menerapkan model pembelajaran Problem Based Learning pada mata pelajaran Dasar Kompetensi Kejuruan Teknik Mesindi kelas XI TFL SMK Negeri 2 Kota Bandung dapat disimpulkan sebagai berikut:

1. Peningkatan hasil belajar siswa pada kompetensi dasar mendeskripsikan proses dasar pengelasan, ranah kognitif pada kategori $N$-Gain tinggi, ranah afektif 
pada kategori positif/baik, sedangkan ranah psikomotor pada kategori amat baik.

2. Model pembelajaran problem based learning dengan menggunakan metode diskusi kelompok menghasilkan nilai peningkatkan aktivitas belajar siswa pada kategori rendah pada kompetensi dasar mendeskripsikan proses dasar pengelasan.

\section{DAFTAR PUSTAKA}

Ahmad, A.J. (2009). Pendekatan Spices dan Problem Based Learning (PBL). [online]. Tersedia: staff.ui.ac.id/SPICESDANPROBLEMBASEDLEARNING2009.doc. [20 Mei 2010]

Amir, Taufiq. (2009). Inovasi Pendidikan Melalui Problem Based Learning. Jakarta: Kencana.

Arikunto, Suharsimi. (2005). Dasar-Dasar Evaluasi Pendidikan. Jakarta: Rineka Cipta.

Graaff, E. dan Kolmos, H. (2009).Research on PBL Practice in Engineering Education: Sense Publisher [online]. Tersedia: https://www.sensepublishers.com/files/9789087909321PR.pddf [15Juni 2010]

Hake, Richard.(1998).Analyzing Change/Gain Scores.[Online].Tersedia:physics.indiana.edu/ sdi/ajpv3i.pdf [20 Mei 2010]

Panggabean, Luhut (2006). Penelitian Pendidikan. Bandung : FPMIPA UPI.

Saptono, Rahmat. (2003). Is Problem Based Learning (PBL) a Better Approach for Engineering Education? CAFEO-21 (21st Conference of the Asian Federation of Engineering Organization).

Supardi, suharsimi, A. dan Suhardjono.(2009). Penelitian Tindakan Kelas. Jakarta: Bumi Akasara.

Trianto.(2007). Model-Model Pembelajaran Inovatif Berorientasi Konstruktivis. Jakarta: Prestasi Pustaka Publisher.

Turyanto, Ragil. (2007). Case (Problem) Based Learning. 